\title{
Evaluation of selected agroforestry practices and farmers' perceptions of climate change in Ogun state, Nigeria
}

\begin{abstract}
Climate change is currently the greatest environmental challenge of the 21 st century. This study evaluated selected agroforestry practices and farmers' perception of climate change in Ogun state. Multistage sampling technique was used to select 240 respondents involved in Agroforestry practices from four agricultural zones in Ogun State (Abeokuta, Ilaro, Ikenne and Ijebu-Ode). Data were collected with the aid of structured and pre-tested questionnaire administered interpersonally to the respondents. The data were analyzed using descriptive statistics, Likert scale and Chisquare analyses. Seven agroforestry practices were identified in the study area, out of which 'scattered trees on farmland' was predominantly practiced $(77.5 \%)$ when prioritized. Likert scale analysis showed that $(96.7 \%)$ agreed that there have been changes in climatic variables such as rainfall and temperature in the last five years. The Chi-square analysis revealed a significant association $(\mathrm{p}<0.05)$ between the perception of respondents' need to mitigate the effect of climate change and their socio-economic variables such as age. The major problem associated with agroforestry practices was insufficient capital to run the farms.
\end{abstract}

Keywords: evaluation, climate change, perception, agroforestry, likert scale
Volume I Issue I - 2017

\author{
IA Kareem,' MF Adekunle,' DA Adegbite, ${ }^{2}$ JA \\ Soaga' \\ 'Department of Forestry and Wildlife Management, Federal \\ University of Agriculture, Abeokuta, Nigeria \\ ${ }^{2}$ Department of Agricultural Economics and Farm Management, \\ Federal University of Agriculture, Abeokuta, Nigeria
}

Correspondence: Idayat Ayoka Kareem, Department of Forestry and Wildlife Management, Federal University of Agriculture,Abeokuta, Nigeria, Email idayahkareem@gmail.com

Received: July 15, 2017 | Published: August 17, 2017

\section{Introduction}

Globally, the climate change problem is manifesting through, amongst others, unusually high temperatures, floods, droughts, unreliable water supplies, enhanced migration of flora and fauna, melting glaciers and decreasing mountain snow caps. For example, the mosquito belt has considerably expanded to higher elevations due to the temperature incline. The frequency and intensity of forest fires has increased due to abundance of fuel and droughts. The scenario is that, the interaction between climate change and national socio-economic policies will drastically reduce crop yields in the foreseeable future in most African countries. River flows and water stocks in reservoirs may decline considerably under a warmer climate while forest ecosystems are predicted to shift their ranges and lose some of their bio-diversity with consequential impoverishment in the natural heritage of the countries and a decline in tourism. The impacts of climate change, whether bio-physical, social or economic, are therefore a source of great concern to practically all African countries.

As more scientific information about global warming accumulates, climate change is emerging as perhaps the greatest environmental challenge of the 21 st century. What is more, a virtual Pandora's Box of major global threats, such as hunger, poverty, population growth, armed conflict, displacement, air pollution, soil degradation, desertification and deforestation are intricately intertwined with and all contribute to climate change, necessitating a comprehensive approach to a solution. Rising to this challenge will entail unprecedented cooperation among the world's nations and strong support from international organizations concerned. FAO is particularly implicated, as its domain encompasses major sources of greenhouse gases, major potential victims of climate change, and major mitigation potentials through carbon pools and "sinks".
Forests have four major roles in climate change. These are that they currently contribute about one-sixth of global carbon emissions when cleared, overused or degraded; they react sensitively to a changing climate; when managed sustainably, they produce wood fuels as a benign alternative to fossil fuels; they have the potential to absorb about one-tenth of global carbon emissions projected for the first half of this century into their biomass, soils and products and store them in principle in perpetuity.

Agroforestry - a dynamic, ecologically based natural resource management system that, through the integration of trees on farms and in agricultural landscape, diversifies and sustains production for increased social, economic and environmental benefits for land users at all levels - also contributes to climate change mitigation, since trees and shrubs absorb more carbon than crops. ${ }^{2}$ The IPCC reports that agroforestry has the potential to sequester nearly $600 \mathrm{Mt}$ carbon dioxide a year by $2040 .{ }^{3}$ As a result of climate change, agriculture is being seriously threatened by rising temperatures, changes in rainfall patterns leading to drought in some regions; and flooding in other areas. Food security is an increasingly important issue for the rural communities who rely on agriculture to meet their subsistence needs. Adaptation to climate change is thus a major concern. Agro forestry practices for mitigating climate change aim at reducing deforestation and maintaining soil fertility. ${ }^{2}$ Agro forestry system of land management will allow for sustainable levels of food production while maintaining soil fertility, providing reasonable supplies of firewood, fodder for animals, traditional medicine, and ornamentals and protecting the soil and water catchments area. ${ }^{4}$ United Nations Development Program ${ }^{5}$ revealed that, the development of agriculture in Nigeria is not meeting the demand of its teeming-population, despite the country's endowment with abundant and diversified range of natural, human and capital resources as well as oil revenue, it has 
remained one of the poorest countries in Africa.

The Objectives of the study are to:

a. Assess farmers' understanding, knowledge and perception of climate change variables on the selected agro forestry practices

b. Describe the pattern of coping strategies that are used to mitigate the effects of climate change on agro forestry practices

c. Identify the problems or challenges faced by agroforestry farmers

\section{Methodology}

The study area is Ogun State, otherwise known as the Gateway State. Ogun State was created out of the former Western State of Nigeria on February 3, 1976 and the State capital is Abeokuta. Ogun State is situated within the tropics, with a total land area of 16 , $409.26 \mathrm{sq} . \mathrm{km}$, lies within latitude $6^{\circ} 20^{\prime}$ and $7^{\circ} 58^{\prime}$ in the tropics and longitude $2^{\circ} 40^{\prime}$ and $4^{\circ} 35^{`}$ East of the Greenwich Meridian, and has an estimated population of 3,728,098 people $^{5}$ of which 67 percent are farmers. ${ }^{7}$ Ogun State shares boundaries with Lagos State in the south, Republic of Benin in the west, Ondo State in the East, Oyo and Osun States in the north.

\section{Source of data}

This study was based on both primary and secondary data. The primary data were obtained through the administration of a structured questionnaire on the respondents. Information obtained through administration of questionnaire was supplemented with secondary data which were obtained from journals, monographs, Central Bank of Nigeria $(\mathrm{CBN})$ and Food and Agricultural Organization Statistics (FAOSTAT).

\section{Sampling method}

A multistage Sampling technique was used to collect data for this study. Sixty (60) farmers were selected randomly from each of the four (4) agricultural zones (Abeokuta, Ilaro, Ikenne and Ijebu-ode) in the state which gave a total of two hundred and forty respondents (240) for the study. The structured questionnaire was used to elicit relevant data from the farmers. The schedule of sampling of respondents is presented in (Table 1).

Table I Prioritization of agroforestry practices in the study area

\begin{tabular}{llll}
\hline Agroforestry practices & Frequency* & Percent & $\begin{array}{l}\text { Order of } \\
\text { priority }\end{array}$ \\
\hline Scattered trees on farmland & 186 & 77.5 & 1 \\
Agrisilviculture & 165 & 68.7 & 2 \\
Biomass Transfer & 90 & 37.5 & 3 \\
Improved fallow & 83 & 34.6 & 4 \\
Alley cropping/Hedgerows & 45 & 18.6 & 5 \\
Home garden & 33 & 13.8 & 6 \\
Live fencing & 12 & 5 & 7 \\
\hline
\end{tabular}

*Multiple responses

The stages of the sampling are as follows:

Multistage: Stages $\rightarrow$ Division of the zones into 4 to produce primary selection units
Stage 1: $\quad$ produce primary selection units $\rightarrow$ zones $(4)-$ Abeokuta, Ilaro, Ikenne and Ijebu- ode

Stage 2: $\quad$ Zones $\rightarrow$ Blocks 2 blocks were purposively selected from each zone

Stage 3: $\quad$ Blocks $\rightarrow$ Cells 3 cells were purposively selected from each block

Stage 4: Simple Random Selection of 10 respondents from each cell which gave a total of 240 respondents

\section{Methods of data analysis}

\section{The analysis of variance (ANOVA)}

This is basically an arithmetic method for breaking down the total variation of the collected data into components representing the sources of variation recognized in the experiment. The sources of variation were determined by the criteria used to classify the observation, the possible interrelationships between these criteria, and experimental and / or sampling error in the data.

\section{Chi-square $\left(\mathrm{X}^{2}\right)$ Test of independence or associations}

The Chi-square analytical tool was used to test for independence or association using contingency tables. The Chi-square test helps in deciding whether to accept or reject the $\mathrm{H}_{\mathrm{O}}$ or $\mathrm{H}_{\mathrm{A}}$ hypothesis from a given set of observations.

Chi -square is calculated using the model:

$$
X^{2}=\sum_{i=1}^{n} \frac{(O i j-E i j) 2}{E i j}
$$

Where $\mathrm{X}^{2}=$ Chi - square

$\Sigma=$ Symbol of sum

Oij $=$ Observed cell frequencies

Eij $=$ Expected cell frequencies

The degree of freedom (df) for $\mathrm{X}^{2}$ test of this type is given thus:

$$
\mathrm{df}=(\mathrm{r}-1)(\mathrm{c}-1)
$$

Where $r$ is the number of rows in the contingency table, and $\mathrm{c}$ is the number of columns.

\section{Hypothesis}

Ho: There is no significant difference in the perception of farmers to mitigate the effect of climate change in the study area

Ha: There is significant difference in the perception of farmers to mitigate the effect of climate change in the study area

\section{Likert scale analysis}

This was adopted to evaluate farmers' perception of climate change in agroforestry practices in the study area. This is an ordered one dimensional scale from which respondents chooses one option that best aligns with their view out of five available options. A common one in this analysis was ascertained with which person may agree or disagree to varying degrees. For scoring, numbers (from 1-5) will be assigned to each option. Class boundaries of mean were also used to draw the inferences. ${ }^{8}$ 
The options with their grading or scoring number are: Strongly agree $=5$; Agree $=4 ; \quad$ Undecided $=3 ; \quad$ Disagree $=2 ;$ and strongly disagree $=1$. For inferences, class boundaries are:

$\leq 1.0<1.5=$ strongly disagree, $\geq 1.5<2.5=$ disagree

$\geq 2.5<3.5=$ undecided; $\geq 3.5<4.5=$ agree and

$\geq 4.5 \leq 5.0=$ strongly agree

\section{Results and discussion}

\section{Prioritization of agroforestry practices in the study area}

Seven different agroforestry practices were identified in the study area (Table 1). Accordingly, Scattered trees on farmland was the most predominantly practiced involving $77.5 \%$ of the respondents; Agrisilviculture (which involved planting of trees with agronomic crop only) was the second in order of priority with $68.7 \%$ followed by Biomass Transfer (37.5\%), and improved fallow (34.6\%). Other agroforestry practices that were frequently practiced include alley cropping (18.6\%); home garden (13.8\%) and live fencing (5\%).

\section{Distribution of respondents by perception on benefits of agroforestry practices}

The benefits of agroforestry practices across the zones were summarized in Table 2. Respondents across the zone agreed that Trees hinder the growth and yield of agronomic crops with a total mean of 4.317 .

Table 2 Distribution of respondents by perception on benefits of agroforestry practices zonal mean

\begin{tabular}{|c|c|c|c|c|c|c|}
\hline Perceptional statement & Abeokuta & ljebu-ode & Ilaro & Ikenne & Mean & Inference \\
\hline Trees hinder the growth and yield of agronomic crops & 4.017 & 4.067 & 4.683 & 4.5 & 4.317 & Agree \\
\hline Leguminous trees improve soil fertility & 4.167 & 3.9 & 4 & 4.367 & 4.108 & Agree \\
\hline $\begin{array}{l}\text { Leguminous trees/shrubs promote yield of crops and increase } \\
\text { farmers' income }\end{array}$ & 4.133 & 3.8 & 4.2 & 4.467 & 4.15 & Agree \\
\hline Dung of animals serve as manure to crops & 3.733 & 3.4 & 3.733 & 3.983 & 3.713 & Agree \\
\hline Trees prevent soil erosion & 4.567 & 4.55 & 4.167 & 4.583 & 4.467 & Agree \\
\hline Trees provide shade and protection against windbreaks & 4.517 & 4.583 & 4.317 & 4.55 & 4.492 & Agree \\
\hline $\begin{array}{l}\text { Trees, crops, animals provide food, timber fuelwood, fodder, } \\
\text { hides, medicines for human benefits/ uses }\end{array}$ & 4.9 & 4.933 & 4.9 & 4.95 & 4.921 & Strongly agree \\
\hline $\begin{array}{l}\text { Returns from trees, crops with/ without animal put more } \\
\text { money into farmers' pocket to improve standard of living }\end{array}$ & 4.833 & 4.933 & 4.967 & 4.917 & 4.913 & Strongly agree \\
\hline
\end{tabular}

\section{Inferences}

$\leq 1.0<1.5=$ strongly disagree, $\geq 1.5<2.5=$ disagree

$\geq 2.5<3.5=$ undecided, $\geq 3.5<4.5=$ agree

\section{$\geq 4.5 \leq 5.0=$ strongly agree}

Also, majority of the agroforestry farmers across the zones agreed that leguminous trees improve soil fertility as shown in the total mean of 4.108. Furthermore, leguminous trees/shrubs promote yield of crops and increase farmers' income; farmers agreed in all the zones with this statement indicated by total mean value of 4.150 .

As regards whether the use of animals dung serve as manure to crops; some respondents were undecided about it while others agreed to it; and the total mean was 3.713 which implies that on the average, farmers agree that dung of animals serve as manure to crops.

Across the zones in the study area, it was also agreed that trees prevent soil erosion as indicated in the total mean value of 4.467 meaning that all respondents in the study area strongly agree to this fact.

Similarly, the perception of farmers as to whether 'trees provide shade and protection against windbreaks' was not different across the zones with the total mean value of 4.492 which implies that all respondents in the study area strongly agree to this fact.

In a similar development, most respondents strongly agree to the fact that 'Trees agronomic crops, animals, all provide food, timber, fuel wood, fodder, hides, medicines for human benefits/uses' as shown in the total mean value of 4.921 .
Also, most respondents equally strongly agree that 'Returns from trees, agronomic crops, with/without animals put more money into farmers' pocket to improve standard of living'. This can be confirmed with the total mean of 4.913 which infers strongly agree to the fact.

\section{Farmers' perception of changes in climatic variables}

Farmers' perception of changes in climatic variables across the zones in the study area was shown by Table 3 . Respondents agree that 'Temperature has been increasing in the last five years' with total mean of 4.233 which implies that most respondents agreed with the statement.

Also in the same vein, most respondents strongly agree that 'there has been decrease in rain intensity in the last five years' as shown by a total mean of 4.788 which implies that most respondents strongly agree to the fact.

As to whether 'there has been decrease in rain duration' most respondents also strongly agree that it is so; as confirmed by the total mean value of 4.721 . Also regarding whether yield of crops was affected (decrease), most respondents strongly agree that the yield of crops has been affected by the change in climatic variables mentioned above and this was shown in the total mean value of 4.896. 
Table 3 Farmers' perception of changes in climatic variables zonal mean

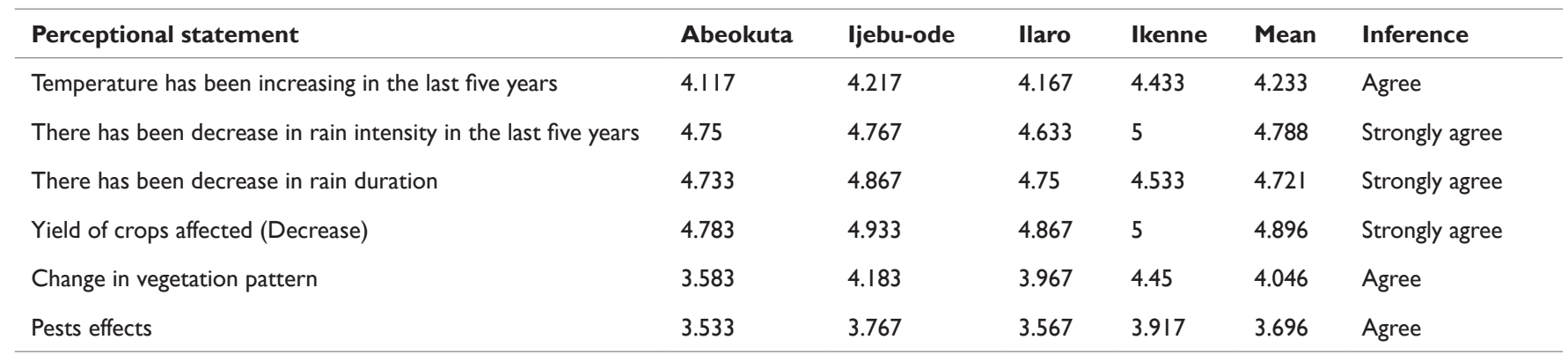

Inferences

$\leq 1.0<1.5=$ strongly disagree, $\geq 1.5<2.5=$ disagree

$\geq 2.5<3.5=$ undecided, $\geq 3.5<4.5=$ agree

$\geq 4.5 \leq 5.0=$ strongly agree

Also most respondents agree that there has been 'change in vegetation pattern' as shown by the total mean value of 4.046 meaning that most respondents also agree to this fact.

In the same vein, farmers' agree that there has been 'pest effect' on yield of crops as a result of changes in climatic variables mentioned earlier. This was evident in the total mean values of 3.696 which imply that most respondents agree to this fact.

Therefore, it can be concluded that there has been changes in climatic variables in the last five years across the zones in the study area, since most farmers perceived it to be so.

\section{Farmers' perceived causes of climate change}

Farmers' Perception on causes of Climate Change was summarized in Table 4. As one of the perceived causes of climate change, Modernization has been agreed upon by most respondents across the

Table 4 Farmers' perceived causes of climate change

\begin{tabular}{|c|c|c|c|c|c|c|}
\hline Causes & Abeokuta & ljebu-ode & Ilaro & Ikenne & Mean & Inference \\
\hline Modernization (Tractorization) & 3.75 & 3.4 & 4.133 & 4.1 & 3.846 & Agree \\
\hline Population Increase & 3.583 & 3.683 & 3.033 & 3.867 & 3.542 & Agree \\
\hline Divine Retribution & 4.95 & 4.95 & 4.817 & 5 & 4.929 & strongly agree \\
\hline Slash \& Burn system for Agriculture & 2.967 & 3.183 & 2.683 & 2.867 & 2.925 & Undecided \\
\hline Firewood collection & 3.233 & 3.25 & 3.25 & 3.2 & 3.233 & Undecided \\
\hline Other Perceived causes of climate change & 0.167 & 0 & 0 & 0 & 0.042 & strongly disagree \\
\hline
\end{tabular}

\section{Inferences}

$\leq 1.0<1.5=$ strongly disagree, $\geq 1.5<2.5=$ disagree

$\geq 2.5<3.5=$ undecided, $\geq 3.5<4.5=$ agree

\section{$\geq 4.5 \leq 5.0=$ strongly agree}

Also, most respondents were undecided as to whether firewood collection is a cause of climate change; as indicated by the total mean of 3.233 which implies that the respondents are undecided about this point.

As regards other perceived causes of climate change, respondents across all the zones strongly disagree that there were other measures that could cause climate change in the study area as indicated by zones as indicated by the total mean values of 3.846 which imply that respondents in the study area agreed that modernization in terms tractorization, use of modernized farm equipment, deforestation and establishment of quarries within and around farm locations are causes of climate change. Also in a similar development, population increase was also agreed on by most respondents as a cause of climate change as shown by the total mean values of 3.542 which infer that most respondents agree to this fact.

Also, across the zones in the study area, most respondents strongly perceived that climate change was divinely retributed as confirmed by the total mean value of 4.929 which infer that most respondents agree that 'Divine Retribution' is a main cause of climate change in the study area. In contrast, most farmers in the study area were undecided about whether slash and burn system of agriculture is also a cause of climate change. This was evident in the total mean values of 2.925 meaning that the respondents are undecided about it. 
climate change, most of the agroforestry farmers were undecided as to whether late planting is a measure to mitigate the effect of climate change; this is reflected in the total mean value of 2.829 meaning undecided to the fact. Reduced length of crop cycle was another measure which most respondents across the zones strongly agree that could mitigate the effect of climate change as shown by the total mean of 4.279 which infer that most respondents strongly agree that reduced length of crop cycle can mitigate the effect of climate change across the zones.

Table 5 Farmers' perceived measures to mitigate the effect of climate change zonal mean

\begin{tabular}{lllllll}
\hline & Abeokuta & ljebu- ode & Ilaro & Ikenne & Mean & Inference \\
\hline Late Planting & 2.883 & 2.6 & 2.9 & 2.933 & 2.829 & Undecided \\
Reduced length of crop cycle & 4.417 & 4.133 & 4.35 & 4.217 & 4.279 & Agree \\
Involve in off-farm activities & 4.467 & 4.267 & 4.233 & 4.467 & 4.358 & Agree \\
Change crop Mix & 4.25 & 4.717 & 4.75 & 4.033 & 4.438 & Agree \\
Other measures & 0.833 & 0.083 & 0 & 0 & 0.229 & Strongly disagree \\
\hline
\end{tabular}

\section{Inferences}

$\leq 1.0<1.5=$ strongly disagree, $\geq 1.5<2.5=$ disagree

$\geq 2.5<3.5=$ undecided, $\geq 3.5<4.5=$ agree

\section{$\geq 4.5 \leq 5.0=$ strongly agree}

Also, Involvement in off-farm activities was perceived by farmers as another measure to mitigate the effect of climate change; this was evident in the total mean value of 4.358 which implies that most respondent agree with this fact. Also as part of measures to mitigate the effect of climate change, most of the respondents agree that changing the crop mix could assist; as indicated by the total mean value of 4.438 which implies that most respondents agree with this fact.

Other measures perceived by agroforestry farmers to mitigate the effect of climate change across the zones include use of irrigation techniques, early planting and monitoring of weather forecast. However, some of the respondents strongly disagree with this; as shown by the total mean value of 0.229 which implies strongly disagree to the statement.

\section{The chi-square results}

The chi-square analysis on the benefits of agroforestry practices show that the test was significantly different from zero at $5 \%$ level of significance, since the chi-square calculated was greater than the tabulated (Table 6).

Table 6 Chi-square analysis on benefits of agroforestry practices zonal mean

\begin{tabular}{llllll}
\hline & O & E & O-E & $(\mathbf{O}-E)^{2}$ & $(\mathbf{O - E})^{2} / \mathbf{E}$ \\
\hline Strongly disagree & 2 & 96 & -94 & 8836 & 92.04167 \\
Disagree & 16 & 216 & -200 & 40000 & 185.1852 \\
Undecided & 151 & 456 & -305 & 93025 & 204.0022 \\
Agree & 821 & 576 & 245 & 60025 & 104.2101 \\
Strongly agree & 930 & 576 & 354 & 125316 & 217.5625 \\
& & & & Chi-square & $\mathbf{7 1 0 . 9 6}$ \\
\hline
\end{tabular}

Degree of freedom $=(r-1)(c-1)=7 * 4=28$

Chi-square $\mathrm{Cal}=710.96$

Chi-square Obs/tab/stat $(p<0.05)=41.34$

Also, the chi-square analysis on Farmers' perceived changes and causes of climate change were significant (Table 7) (Table 8).
Table 7 Chi-square analysis on farmers' observed changes in climatic variables

\begin{tabular}{llllll}
\hline & O & E & O-E & $(\text { O-E })^{2}$ & $(\text { O-E })^{2} / E$ \\
\hline Strongly disagree & 0 & 0 & 0 & 0 & 0 \\
Disagree & 5 & 260 & -255 & 65025 & 250.0962 \\
Undecided & 122 & 260 & -138 & 19044 & 73.24615 \\
Agree & 778 & 580 & 198 & 39204 & 67.5931 \\
Strongly agree & 775 & 580 & 195 & 38025 & 65.56034 \\
& & & & Chi-square & $\mathbf{4 5 6 . 4 9}$
\end{tabular}

Degree of freedom $=(r-I)(c-I)=6 * 4=24$

Chi-square $\mathrm{Cal}=456.49$

Chi-square Obs/tab/stat $(p<0.05)=36.42$

Table 8 Chi-square analysis on farmers' perceived causes of climate change

\begin{tabular}{llllll}
\hline & O & E & O-E & $(\text { O-E })^{2}$ & $(\text { o-E })^{2} / E$ \\
\hline Strongly disagree & 3 & 96 & -93 & 8649 & 90.09375 \\
Disagree & 212 & 276 & -64 & 4096 & 14.84058 \\
Undecided & 251 & 276 & -25 & 625 & 2.264493 \\
Agree & 416 & 276 & 140 & 19600 & 71.01449 \\
Strongly agree & 320 & 396 & -76 & 5776 & 14.58586 \\
& & & & Chi-square & 192.79 \\
\hline
\end{tabular}

Degree of freedom $=(r-I)(c-I)=5 * 4=20$

Chi-square $\mathrm{Cal}=192.79$

Chi-square Obs/tab/stat $(p<0.05)=31.41$

In the same vein, the chi-square analysis on the measures to mitigate the effect of climate change was also significant (Table 9).

Conclusively, it can be inferred that there is significant difference in the perception of farmers to mitigate the effect of climate change in the study area since chi-square calculated was greater than the 
tabulated in all instances; therefore, the null hypothesis Ho is rejected and $\mathrm{Ha}$ is accepted.

Table 9 Chi-square analysis on measures to mitigate effect of climate change

\begin{tabular}{llllll}
\hline & O & E & O-E & $(\text { O-E })^{2}$ & $(\text { O-E })^{2} / E$ \\
\hline Strongly disagree & 1 & 48 & -47 & 2209 & 46.02083 \\
Disagree & 127 & 168 & $-4 I$ & 1681 & 10.00595 \\
Undecided & 139 & 248 & -109 & $1188 \mathrm{I}$ & 47.90726 \\
Agree & 320 & 248 & 72 & 5184 & 20.90323 \\
Strongly agree & 384 & 368 & 16 & 256 & 0.695652 \\
& & & & Chi-square & 125.53
\end{tabular}

Degree of freedom $=(r-I)(c-I)=4 * 4=16$

Chi-square $\mathrm{Cal}=\mid 25.53$

Chi-square Obs/tab/stat $(p<0.05)=26.29$

Problems faced by agroforestry farmers in the study area

Figure 1 shows the Problems facing Agroforestry practices in the study area: The most prominent problem associated with agroforestry practices was insufficient capital or funds to run the farm with $100 \%$, followed by Rodent Infestation with $(99.6 \%)$, while Inadequate Rainfall had $99.2 \%$. Other pressing problems include Pest Attack $(97.5 \%)$ and Instability of market prices $93.3 \%$.

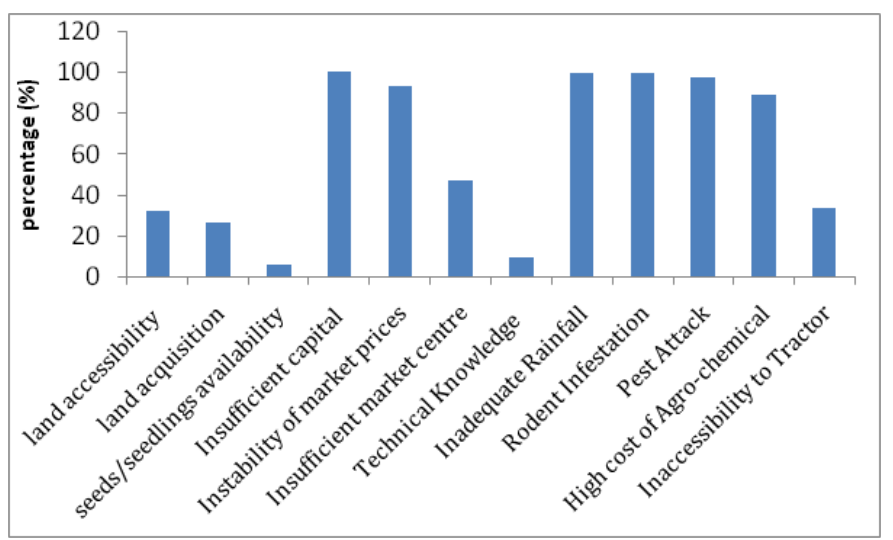

Figure I Problems associated with agroforestry practices

\section{Discussion}

On Farmers' Perception of climate change, majority (97.5\%) of the farmers agreed that temperature has been increasing in the last five years. This result agreed with. ${ }^{9}$ that $89.5 \%$ of farmers perceived that long-term temperatures are increasing. Climate changes adversely affect the population and variety of plant and animal species in the forest, resulting in the scarcity or out-right extinction of many important plant and animal species. ${ }^{10}$ Some plant and animal genetic resources that could be used in producing new pharmaceuticals or traditional medicine are lost as a result of the destruction of forest cover by climate change.

The perception of farmers on decrease in rain intensity and rain duration shows that majority (99.2\%) agreed that rain intensity and $(99.6 \%)$ agreed that rain duration have decreased respectively. This finding is also in line with ${ }^{9}$ that $54.3 \%$ and $36.5 \%$ of the farmers perceived that there have been changes in timing of rains and decrease in rainfall pattern respectively in Ondo State. The results also agreed with $^{11}$ findings that perception on climate change showed that a significant number of farmers believe that temperature has already increased and that rainfall pattern has declined for eleven African countries. Also, the result of ${ }^{12}$ revealed that larger percentage of the farmers observed the effect of change in rainfall on their crop produce ${ }^{13}$ reported that the effect of change in rainfall resulted in adjusting the timing of farm operations such as planting or sowing dates and treatments; the study shows that $89.89 \%$ of the respondents observed change in rainfall during the year while $64.04 \%$ of the respondents observed that change in rainfall usually occurred seasonally.

A better understanding of farmers' perceptions regarding longterm climatic changes (such as rainfall, and temperature), current adaptation measures and their determinants will be important to inform policy for future successful adaptation of the agricultural and forestry sector.

This study found that agroforestry has socio-economic benefits in the study area, $89.6 \%$ of respondents agreed that leguminous trees/ shrubs promote yield of crops and increase farmers' income and all $(100 \%)$ of the farmers agreed that trees prevent soil erosion, provide shade and protection against wind. Also, $98 \%$ of the farmers agreed that returns from trees, crops with or without animal put more money into farmers' pocket to improve welfare. These findings are in line with the results of ${ }^{14}$ that the presence of trees on agricultural plots apart from allowing its various components to withstand shock and climate variability can also provide alternatives and additional source of income, thereby strengthening the socio-economic resilience of the people..$^{15,16}$ Tree products are usually of more economic value than most crops such as sorghum and millet, and can therefore buffer against income risk of crop failure. Agroforestry as an integrated land use system has been reported to incorporate high value multi-purpose trees with soil/water conservation structures. The value produced in the form of food, fuel wood, forage, plant nutrients and biomass for mulch contribute to increased infiltration of rain water, and addition of organic matter and control of soil erosion. ${ }^{17}$

The effect of climate change on the farming activities in the study area were evident with low soil moisture content, slow growth rate of crops, increased growing season of crops and reduced yield from farm produce. These claims were confirmed by the findings of ${ }^{18}$ and $; 9$ they claimed that all these problems were as a result of the changes in timing of rainfall. It is no longer easy to predict the onset and cessation period of rains. The prediction of onset and cessation date of rains determines the cultural practice of farmers. Nevertheless, the respondents claimed that they have no choice than to adapt.

Majority (72.9\%) of farmers' perceived causes of climate change to be outcome of modernization and naturally changing times, $59.6 \%$ reported that it was due to high population growth, $97.9 \%$ agreed that it was a divine retribution and $42.9 \%$ attributed it to excessive firewood collection. This report agrees with the result of ${ }^{19}$ that majority $(86 \%)$ of the farmers agreed that there have been profound changes in climatic effects in the last decade which have directly affected crop production practices.

The various measures perceived by agroforestry farmers to mitigate the effects of climate change as revealed in Tables 9 and 23 include planting of short rotation crop $(96.6 \%)$ involvement in off- 
farm activities $(82.9 \%)$ and changing of crop mix (86.3\%). These findings were in line with the results of ${ }^{9}$ and were also confirmed by. ${ }^{20}$ They reported that crop diversification can serve as insurance against rainfall variability as different crops are affected differently by climate events. However, $22.5 \%$ of the farmers agreed that late planting can mitigate the effect of climate change and only $4.6 \%$ agreed that irrigation can be used as other measures to mitigate climate change. These adaptation / mitigation options used by the farmers in the study area can be classified into two main modifications in the production systems. The modifications are increase in diversification and escaping sensitive growth stages through crop management practices. This ensures that critical crop growth stages do not coincide with very harsh climatic conditions in the season. According to,${ }^{21}$ increased diversification through engaging in production activities that are more drought- tolerant and or resistant to temperature stresses as well as activities that make efficient use and take full advantage of the prevailing water are important forms of insurance against rainfall variability. Growing a number of different crops on the same plot or in different plots reduces the risk of complete crop failure as different crops are affected differently by climate events.

The adaptation strategies farmers perceive as appropriate (as opposed to the strategies they actually carry out) include crop diversification; using different crop varieties; varying the planting and harvesting dates; increasing the use of irrigation; increasing the use of water and soil conservation techniques, shading and shelter; shortening the length of the growing season; and diversifying from farming to non-farming activities.

\section{Conclusion}

This study evaluated selected agroforestry practices and farmers perception of climate change in Ogun State. The findings of the research can be concluded thus: Seven agroforestry practices were identified in the study area; these include: scattered trees on farmland, agrisilviculture, biomass transfer, improved fallow, alley cropping, home garden and live fencing. A scattered tree on farmland was the most common agroforestry practice and this was followed by agrisilviculture. Most of the farmers in the study area agreed that there had been changes in climatic variables such as rainfall and temperature which in turn had affected the yield and productivity of the farmers. The most prominent problem that affected the farmers and agroforestry production in the study area was the lack of sufficient capital or funds to run the farm.

\section{Recommendations}

Based on the findings of this research, the following suggestions were recommended:

a. Agroforestry farmers should undergo adult literacy programme to educate them on the appropriate timing of farm operations so as to be able to adapt or mitigate the effect of climate change.

b. Farmers should be encouraged to plant more trees and retain existing ones on their farms so as to be able to mitigate the effect of climate change and also increase farmers' income through sales of timber and non timber forest products.

c. Assistance in the form of subsidy on land, fertilizers, seed / seedlings and other farm inputs should be provided to farmers so that they can change their crop mix and plant crops with reduced length of life cycle which will in turn mitigate the effect of climate change and also boost their productivity.

\section{Acknowledgements}

None.

\section{Conflict of interest}

Author declares that there is no conflict of interest.

\section{References}

1. FAO. CLIM-FO Climate Change and Forestry. Electronic Journal and Newsletter. 2011.

2. Adedire MO. Agroforestry and climate change Mitigation. Proceedings of the $2^{\text {nd }}$ Biennial National Conference of the Forests and Forest Products Society $26^{\text {th }}-29^{\text {th }}$. Akure Nigeria: Federal University of Technology; 2010. p. 69-74.

3. IPCC WGII Fourth Assessment Report. Climate Change 2007: Climate Change Impacts, Adaptation and Vulnerability. Summary for Policy Makers Inter governmental Panel on Climate Change (IPCC). In: Parry ML, Canziani OF, Palutikof JP, editors. Cambridge: Cambridge University Press; 2007. p. 23.

4. Owa O, GN Udom, TA Ampitan, et al. The Contribution of Agroforestry Practices to Crop Production (A Review). A paper Presented at 20th Annual National Conference of Farm Management Association of Nigeria held at Forestry Research Institute of Nigeria. Federal College of Forestry Bauchi, Plateau State.18th - 21st. 2006. p. 550-561.

5. United Nations Development Program (UNDP). Human Development Report, New York, USA: Oxford University Press; 1999.

6. NBS. National Bureau of Statistics Facts and Figures about Nigeria. NBS, Abuja, Nigeria; 2009 .

7. OGADEP Ogun State Agricultural Development Programme. Annual Project Report. 1998. p. 5-6.

8. Del S. Assessment Survey Neag School of Education University of Connecticut. 2010

9. Oyerinde OV, Osanyande OV. Farmers' Adaptation Strategies and Perception to Climate Change: A case study of communities Around Idanre Forest Reserve, Ondo State, Nigeria. Proceedings of the 2nd Biennial National Conference of the Forests and Forest Products Society 26th-29th. 2010

10. Sohngen B, Shugart H, Sedjo R. Emerging Threats to Forests: Resilience and Strategies at System Scale. 2001: 4-6.

11. Mendelsohn R. Climate Change impacts on agriculture. In: Evenson R, Pingali P, Schultz P, editors. Handbook of Agricultural Economics: Agricultural Development. 2006;3:3009-3031.

12. Olafemi SO, Balogun OS, Owonibi DB, et al. Perception and Adaptation of farmers to climate change in Igabi Local Government Area of Kaduna State, Nigeria. Proceedings of the $35^{\text {th }}$ Annual Conference of the forestry Association of Nigeria 11th - 16th. 2013.

13. Burseel SEC. Adapting to Changes: the challenge for European agriculture and rural areas Commission of the European Communities Commission working staff working document accompanying the white papers No.147. 2009

14. Jacob DE, Ufot IN, Sotande AO. Climate Change Adaptation and Mitigation through Agroforestry Principles in the Sahel Region of Nigeria Forestry Association of Nigeria (FAN) Conference. 2013. p. 300-308.

15. Adedire MO. Principles and Practice of Agroforestry in Nigeria: Paper presented at the training workshop on strategies and modalities for the implementation of the Agroforestry sub-component of the nation special program for food security at Lokoja, Kogi State, Nigeria; 2005. 
16. Ogundele JA, Jacob DE. Constraint in the adoption of Agroforestry in the tropics: The case of Nigeria. Journal of Geography, Environment and Planning. 2010;6(2):110-115.

17. Pasternak D, Nikiema A, Fatondji D, et al. The Sahelian Eco-Farm. In: Omanya G, Pasternak D editors. Sustainable Agriculture Systems for the Drylands ICRISAT, Patancheru, India; 2005.

18. Omotosho JB. Long-range prediction of the Onset and end of rainy season in West Africa Sahel. International Journal of Climatology. 1992;12(4):369-382.
19. Agbholahor MU, Ashaolu OF. In Biotechnology development and threat of climate change in Africa: the case of Nigeria. In: Adeboye, editor. Germany: Published by Curvillier Verlag Gottingen, Internationaler Wissenschaftlcher Fachverlag; 2010. p. 124-132.

20. Adger WN, Huq S, Brown K, et al. Adaptation to climate change in the developing world Progress in Development Studies. 2003;3(2):179-195.

21. Nhemachena C, Hassan R. Micro-level Analysis of Farmers' Adaptation to Climate Change in Southern Africa. IFPRI Discussion paper 00714. 2007. 